\title{
Ergosterol Concentration of Several Different Saccharomyces cerevisiae Yeast Strains
}

\author{
MARYKE STRYDOM, ADRIENNE F. KIRSCHBAUM and A. TROMP \\ Oenological and Viticultural Research Institute, Private Bag X5026, Stellenbosch, 7600
}

\begin{abstract}
Differences in the formation of ergosterol in yeast cells have been found amongst several wine yeast strains used in South Africa. A higher ergosterol content is generally accompanied by a faster fermentation rate and results in a shortening of fermentation time. A high ergosterol concentration in the cell is not a prerequisite for maximal cell formation, but probably affects the metabolic activity of the cell. Aeration of the must during the yeast proliferation stage, brought about marked increases in ergosterol concentrations.
\end{abstract}

Ergosterol is the major sterol of Saccharomyces cerevisiae and of a number of other yeast species (Rattray, Schibeci \& Kidby, 1975). Of several hundred fungal strains tested, Sacch. cerevisiae was found to produce the largest quantities of sterols (Dulaney, Stapley \& Simpf, 1954). Under conditions of aerobic growth, it is able to synthesize ergosterol amounting to $2-10 \%$ of its dry mass (Dulaney et al., 1954). The synthesis of sterols depends largely upon the oxygen requirement of the strain, and different strains behave differently in respect of sterol synthesis in the presence of specific concentrations of oxygen in the growth medium (Kirsop, 1974). During anaerobic growth, sterols cannot be synthesized, and unless small quantities of sterol are supplied exogenously, the cells will stop growing after a few generations (David \& Kirsop, 1973).

The presence of molecular oxygen is necessary for the biosynthesis of ergosterol and all other yeast sterols. It is required for several biochemical reactions in the synthesis process, such as the induction of the enzyme 3-hydroxy-3-methylglutaryl-coA reductase, which catalyses the formation of mevalonic acid from 3hydroxy-3-methylglutaryl-coA (Berndt et al., 1973); the cyclisation of squalene to form the first sterol lanosterol (Klein, 1955), as well as several demethylation and desaturation reactions (Aries \& Kirsop, 1978). In the beer industry, aeration of yeast during the stage of proliferation is conducted with the specific aim to boost ergosterol production (Harding \& Kirsop, 1979).

Although the specific function of the sterols in yeast is not clear (Boll et al., 1975), some evidence has been presented suggesting that sterol synthesis and development of respiratory capacity in the cell are closely related (Parks \& Starr, 1963). Proudlock, Haslam \& Linnane (1969) stated that the main function of sterols in yeast is an effect on the structure and dynamic state of the cell membrane and thus on its permeability to growth constituents.

In respect of wine yeast, Lafon (1978) found that the addition to must of growth factors such as thiamine or diammonium phosphate, causes a more rapid onset of fermentation and a higher fermentation rate, while the presence of yeast sterols affects only the final stages of fermentation.

The present paper reports, firstly, on differences observed between locally used wine yeast strains in respect of their ability to synthesize ergosterol and its possible effect on fermentation behaviour; secondly, on the effect of aeration during the stage of yeast proliferation on the subsequent fermentation process.

\section{MATERIALS AND METHODS}

Cultural conditions: In the first experiment steam sterilized, clearly settled Chenin blanc must from the 1979 vintage was used; the second and third experiments were done with sterile filtered Chenin blanc must from the 1979 vintage, and Chenin blanc and Colombar musts from the 1980 vintages respectively. The musts had sugar concentrations of about $200 \mathrm{~g} / \ell$, total $\mathrm{SO}_{2}$ concentrations of $75 \mathrm{mg} / \ell$ and $\mathrm{pH}$ values ranging from 3,3 to 3,4 . Pure cultures were prepared by rehydrating $1 \mathrm{~g}$ dried preparations of the organisms in $10 \mathrm{~m} \ell$ sterile distilled water for $30 \mathrm{~min}$. at $42^{\circ} \mathrm{C}$, and inoculating sterile filtered grape must to a concentration of $0,2 \mathrm{~g}$ pure culture yeast per litre. Inoculations from the pure cultures into the musts to be fermented, were done to a concentration of $5 \%(\mathrm{v} / \mathrm{v})$. The organisms were grown and fermented at $15^{\circ} \mathrm{C}$ in $1500 \mathrm{~m} \ell$ quantities in $2 \ell$ glass containers supplied with stopcocks from which samples could be drawn. All fermentations were done in duplicate.

Fermentation treatments: In the first experiment Sacch. cerevisiae strains WE 14, WE 353 (Epernay), WE 372 and WE 392 (Montrachet) were used. The must of the second experiment was supplemented with $1 \mathrm{~g} / \ell$ $\left(\mathrm{NH}_{4}\right)_{2} \mathrm{HPO}_{4}$ to eliminate the possible effect of nitrogen deficiency. Strains WE 14, WE 372 and WE 392 (Montrachet) were used. In the third experiment aeration was effected by pumping filtered air through the pure cultures for four days at a rate of $25 \mathrm{m \ell} / \mathrm{min}$. Strains WE 14 and WE 432 were used. All organisms came from the culture collection of the Oenological and Viticultural Research Institute, Stellenbosch.

Live cell counts: The number of live cells present at the inoculation stage and during fermentation was determined according to the plate count method on YM agar (Difco) plates. Colonies were counted after incubation at $25^{\circ} \mathrm{C}$ for three days, and the final colony count was taken as the average of three plates per dilution containing 30 to 300 colonies per plate.

Fermentation rate: The mass of the flasks was determined at inoculation - daily for the first four days, and then every second or third day. The mass loss as a result of carbon dioxide development was calculated, and a fermentation rate curve drawn by plotting mass loss/100 $\mathrm{m} \ell$ must medium vs time.

Yeast dry mass: Fifty $m \ell$ samples of the must were tapped after shaking each flask, centrifuged at $4080 \mathrm{~g}$ 
for $20 \mathrm{~min}$., and washed once with $50 \mathrm{~m} \ell$ distilled water. The supernatant was discarded, the cells suspended in $10 \mathrm{~m} \ell 50 \mathrm{mM}$ phosphate buffer of $\mathrm{pH} \mathrm{7,0}$, the suspension filtered through Millipore filters (type HAWP 04600) of known mass, the cells washed with 3 $\mathrm{m} \ell$ distilled water and their mass again determined according to the method of Mas \& Pina (1980) after 24h at $85^{\circ} \mathrm{C}$.

Ergosterol analysis: Fifty $\mathrm{m} \ell$ samples of must were centrifuged at $4080 \mathrm{~g}$ for $20 \mathrm{~min}$., and the cells washed once with an equal volume of distilled water. The washed cells were suspended in $2 \mathrm{~m} \ell$ distilled water, and their ergosterol contents determined by the method of Breivik \& Owades (1957). Absorbances were determined on a Beckman Model 25 spectrophotometer.

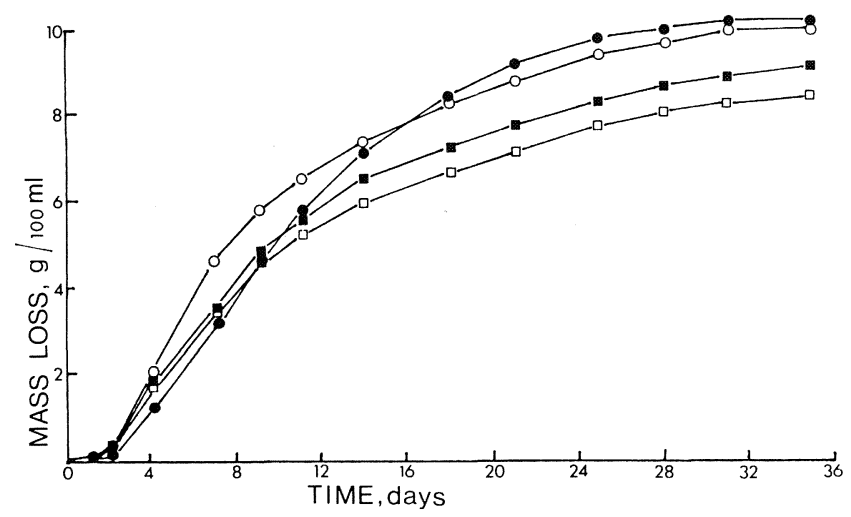

FIG. 1

Fermentation rates of four different wine yeast strains in Chenin blanc must.

- WE 353; O WE 392;

WE 14; $\square$ WE 372

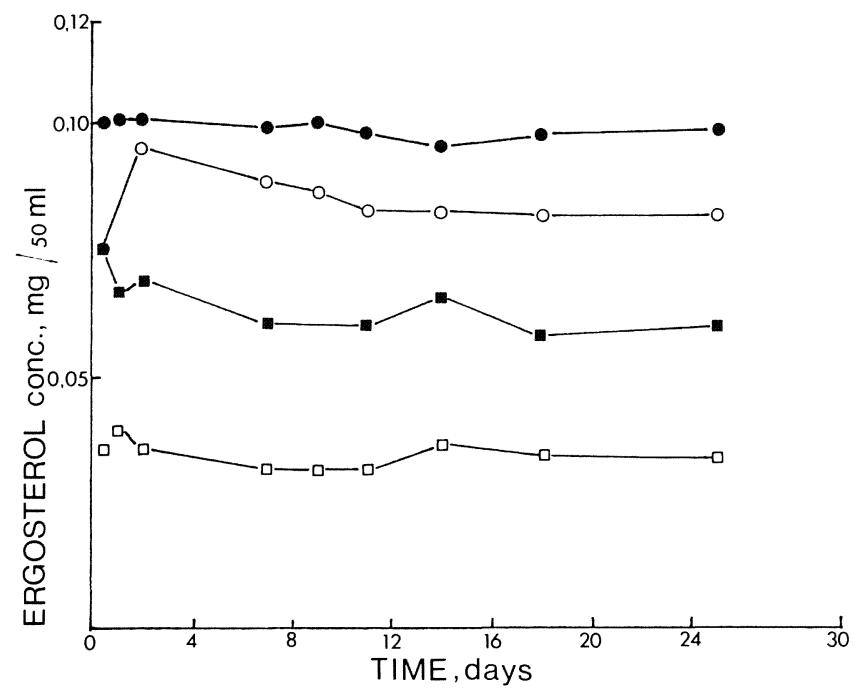

FIG. 3

Ergosterol concentration $(\mathrm{mg} / 50 \mathrm{~m} \ell)$ in a Chenin blanc must fermented with four different wine yeast strains.

- WE 353; O WE 392;

\section{RESULTS AND DISCUSSION}

Ergosterol contents of strains: In the first experiment the effect of ergosterol on the rate of fermentation was studied. Marked differences amongst strains were observed. Fermentation rates, dry yeast mass production, ergosterol content of the cells and in the medium are shown in Figures 1, 2, 3 and 4 respectively. After 35 days the must inoculated with strain WE 353, contained $1,5 \mathrm{~g}$ residual sugar per litre, while strain WE 392 contained 4,7 g/ $\ell$, strain WE 14 16,4 g/ $\ell$ and strain WE 372 27,5 g residual sugar per litre. Only strain WE 353 , therefore, was able to complete fermentation at $15^{\circ} \mathrm{C}$ within a reasonable time. Strain WE 353 also had the highest ergosterol concentration per volume $(0,1 \mathrm{mg} / 50$ $\mathrm{m} \ell)$ and produced the highest level of dry cell mass $(119 \mathrm{mg} / 50 \mathrm{~m} \ell)$. However, ergosterol content expres-

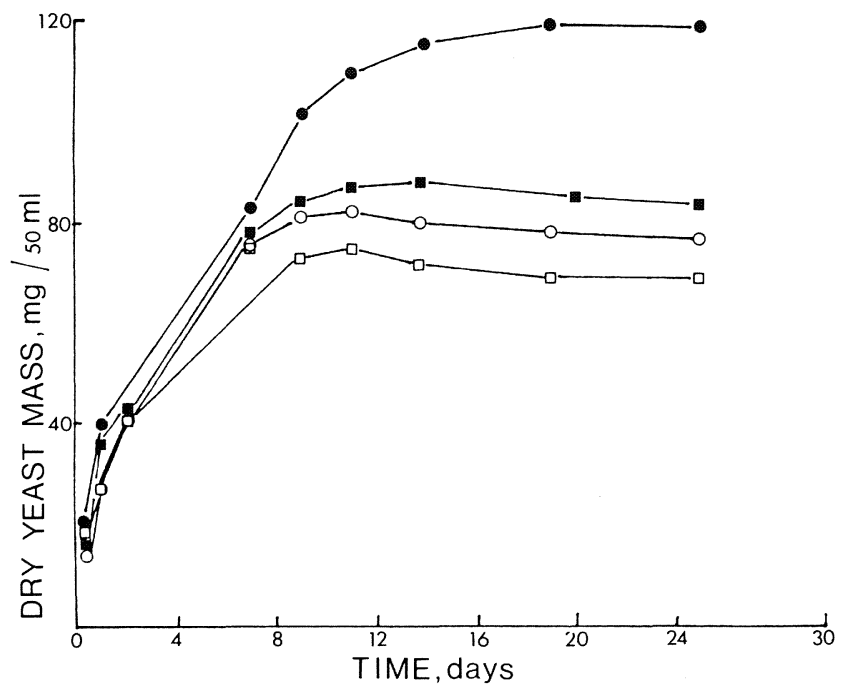

FIG. 2

Dry mass production by four different wine yeast strains in Chenin blanc must.

- WE 353; O WE 392;

WE 14; $\square$ WE 372

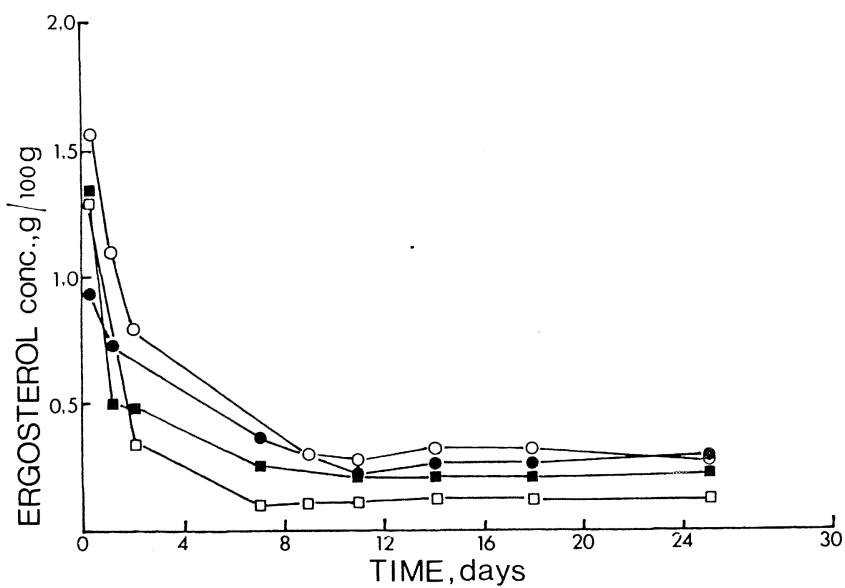

FIG. 4

Ergosterol concentration (dry mass basis) of four different wine yeast strains in Chenin blanc must.

- WE 353; ○ WE 392; —WE 14; $\square$ WE 372 
sed on a dry mass basis for strain WE $353(0,27 \mathrm{~g} / 100 \mathrm{~g})$ was somewhat lower than that of strain WE $392(0,31$ $\mathrm{g} / 100 \mathrm{~g})$. It is of interest to note that strain WE 353, which produced the highest level of total ergosterol in the medium, showed a relatively long lag phase of about 2 days before the onset of fermentation (Fig. 1). However, the fermentation rate of this strain was higher than that of any of the other strains.

In the second experiment the same higher ergosterol content and faster fermentation rate were observed. Results are summarized in Figures 5, 6, 7 and 8, and the live cell counts of the three strains are compared in
Table 1 . Final live cell counts 40 days after inoculation, were in accordance with the ergosterol content and fermentation rate. This is illustrated by strain WE 392 , which at that stage had the highest cell count $(12,8 \mathrm{x}$ $\left.10^{6} / \mathrm{m} \ell\right)$, showed the highest ergosterol content throughout the fermentation period (minimum 0,2 $\mathrm{g} / 100 \mathrm{~g}$ ), and was the first to complete fermentation (47 days). Fermentation behaviour in this case could not be ascribed to the size of the inoculum, as strain WE 372 , the one that fermented most slowly, had the highest inoculum concentration $\left(5,3 \times 10^{6}\right.$ cells $\left./ \mathrm{m} \ell\right)$ compared with $4,8 \times 10^{6}$ cells/m $\ell$ for WE 14 and WE 392).

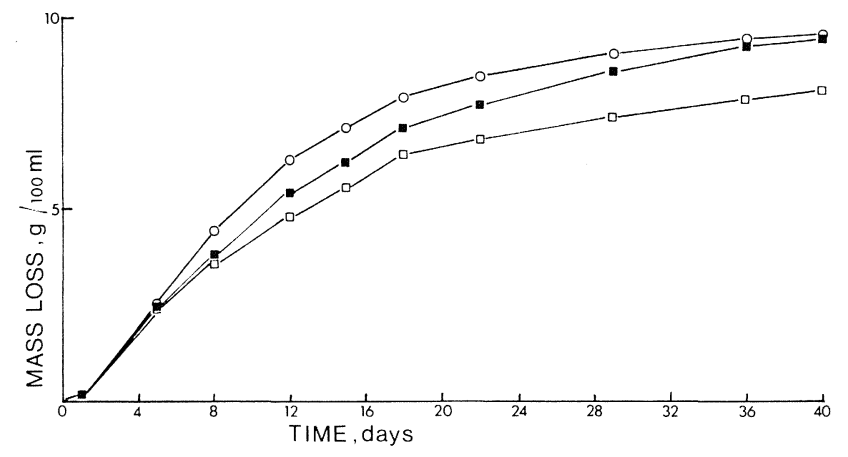

FIG. 5

Fermentation rates of three wine yeast strains in sterile filtered Chenin blanc must.

○ WE 392;

WE 14; $\square$ WE 372

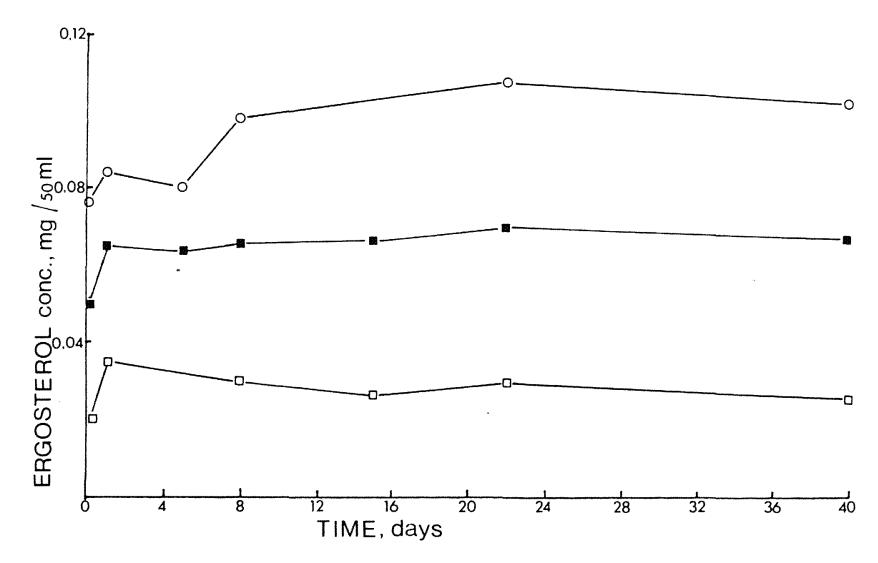

FIG. 7

Ergosterol concentration $(\mathrm{mg} / 50 \mathrm{~m} \ell$ ) in a sterile filtered Chenin blanc must fermented with three different wine yeast ○ WE 392; strains.

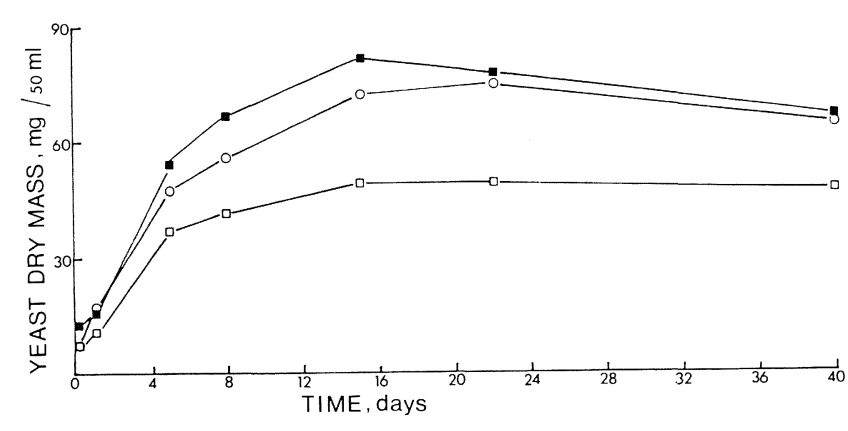

FIG. 6

Dry mass production by three wine yeast strains in sterile filtered Chenin blanc must.

OWE 392; 口WE 14; $\square$ WE 372

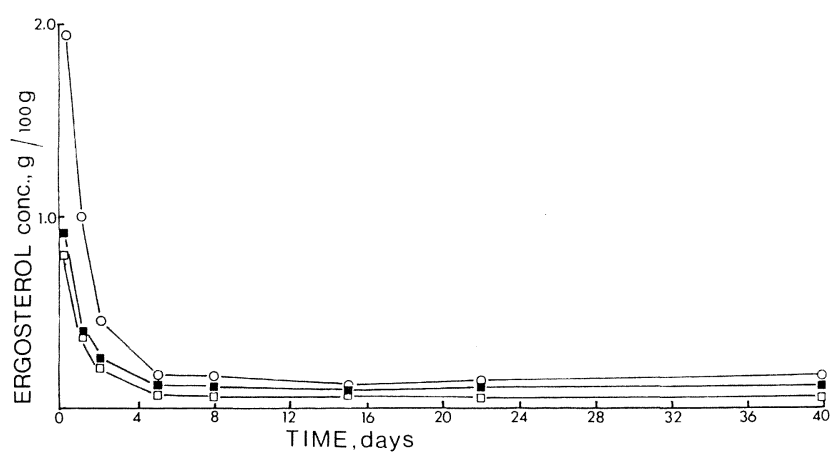

Fig. 8

Ergosterol concentration (dry mass basis) of three wine yeast strains in sterile filtered Chenin blanc must.

OWE 392; 口WE 14; $\square$ WE 372 


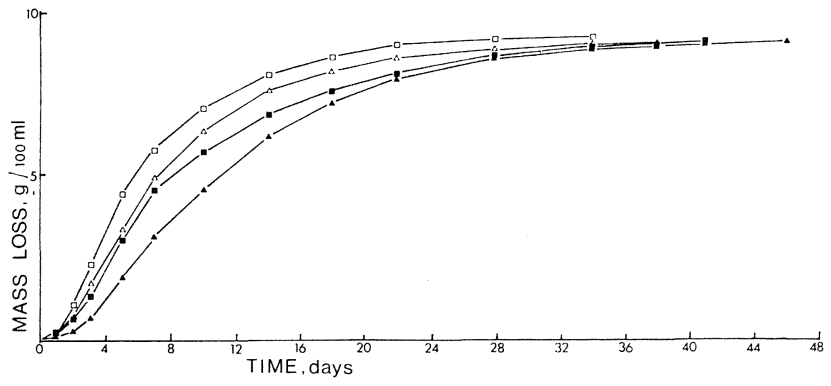

FIG. 9

Fermentation rates of aerated and unaerated pure cultures of two wine yeast strains in sterile filtered Chenin blanc must.

$\square$ WE 14 aerated; WE 14 unaerated; $\triangle$ WE 432 aerated; $\Delta$ WE 432 unaerated

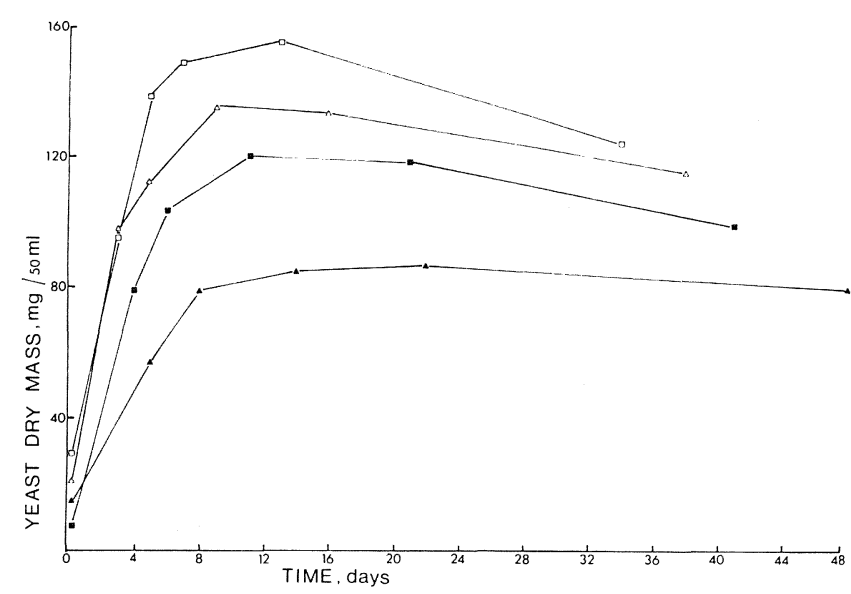

FIg. 11

Dry mass production by aerated and unaerated pure cultures of two wine yeast strains in sterile filtered Chenin blanc must. $\square$ WE 14 aerated;
$\triangle$ WE 432 aerated;

WE 14 unaerated; $\triangle$ WE 432 unaerated

TABLE 1

Live cell counts of strains WE 14, WE 372 and WE 392 during fermentation.

\begin{tabular}{llllr}
\hline \multirow{5}{*}{ Days } & \multicolumn{4}{l}{ Cell count $\left(\times 10^{6} / \mathrm{m} \ell\right)$} \\
\cline { 2 - 5 } & 0 & 5 & 12 & 40 \\
\hline WE 14 & 4,8 & 13,4 & 11,6 & 9,8 \\
WE 372 & 5,3 & 16,5 & 12,4 & 8,0 \\
WE 392 & 4,8 & 10,7 & 11,4 & 12,8 \\
\hline
\end{tabular}

Effect of aeration: Using Chenin blanc must, the results of aeration of pure cultures with regard to fermentation rates, live cell counts, dry cell mass production, ergosterol content in cells and in the media, are given in Figures $9,10,11,12$ and 13 respectively. Similar results were obtained in the case of the Colombar must. (Results not shown.)

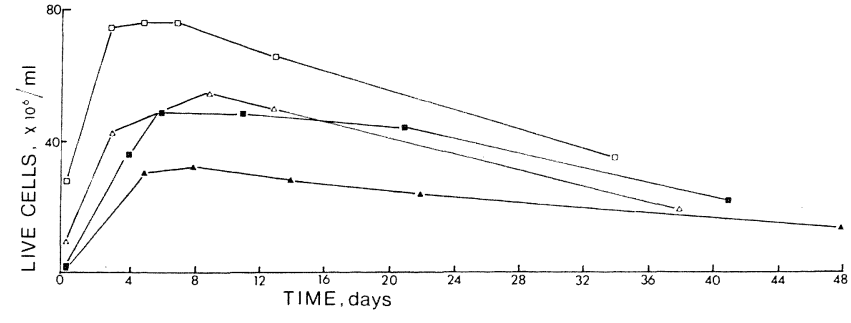

FIG. 10

Live cell counts of aerated and unaerated pure cultures of two wine yeast strains in sterile filtered Chenin blanc must.

$\square$ WE 14 aerated; WE 14 unaerated;
$\triangle$ WE 432 aerated; $\triangle$ WE 432 unaerated

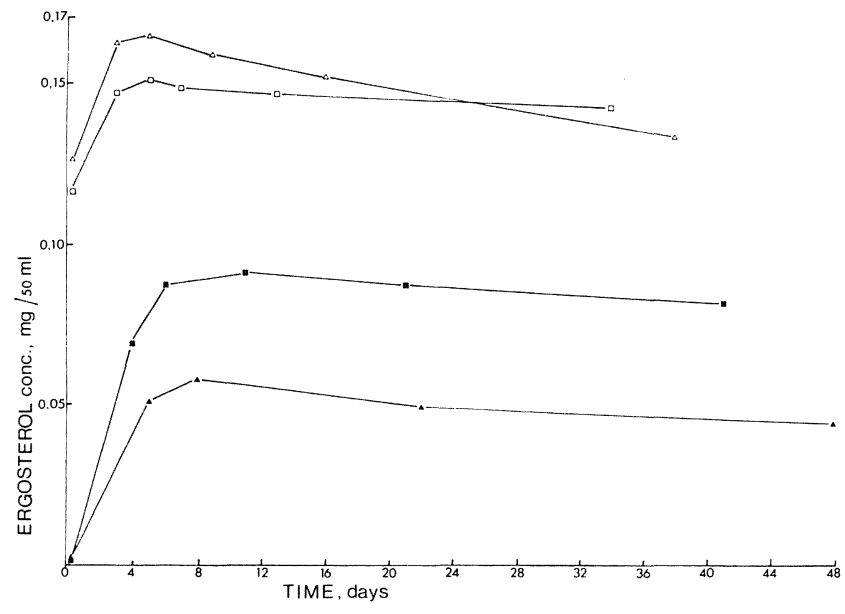

FIG. 12

Ergosterol concentration $(\mathrm{mg} / 50 \mathrm{~m} \ell)$ in a sterile filtered Chenin blanc must fermented with aerated and unaerated pure cultures of two wine yeast strains.
$\square$ WE 14 aerated;
WE 14 unaerated;

$\triangle$ WE 432 aerated

WE 432 unaerated

As can be seen from Figure 9, aeration of both strains led to a higher fermentation rate and earlier completion of fermentation. In the case of WE 14, fermentation with the aerated pure culture was completed within 34 days after inoculation, while the unaerated culture required 41 days. With strain WE 432 this difference was of the same order, with 38 days for the aerated and 46 days for the unaerated culture. In Table 2 the inoculation cell concentrations, final ergosterol contents per cell and per volume, as well as the duration of fermentation are compared for both strains and both cultivars. It can be seen that although the inoculum sizes differed largely, the final ergosterol contents on a dry mass basis were much higher in the case of the aerated cultures (13 times higher than the unaerated culture for strain WE 14 , and about 30 times higher than the unaerated culture for strain WE 432). 


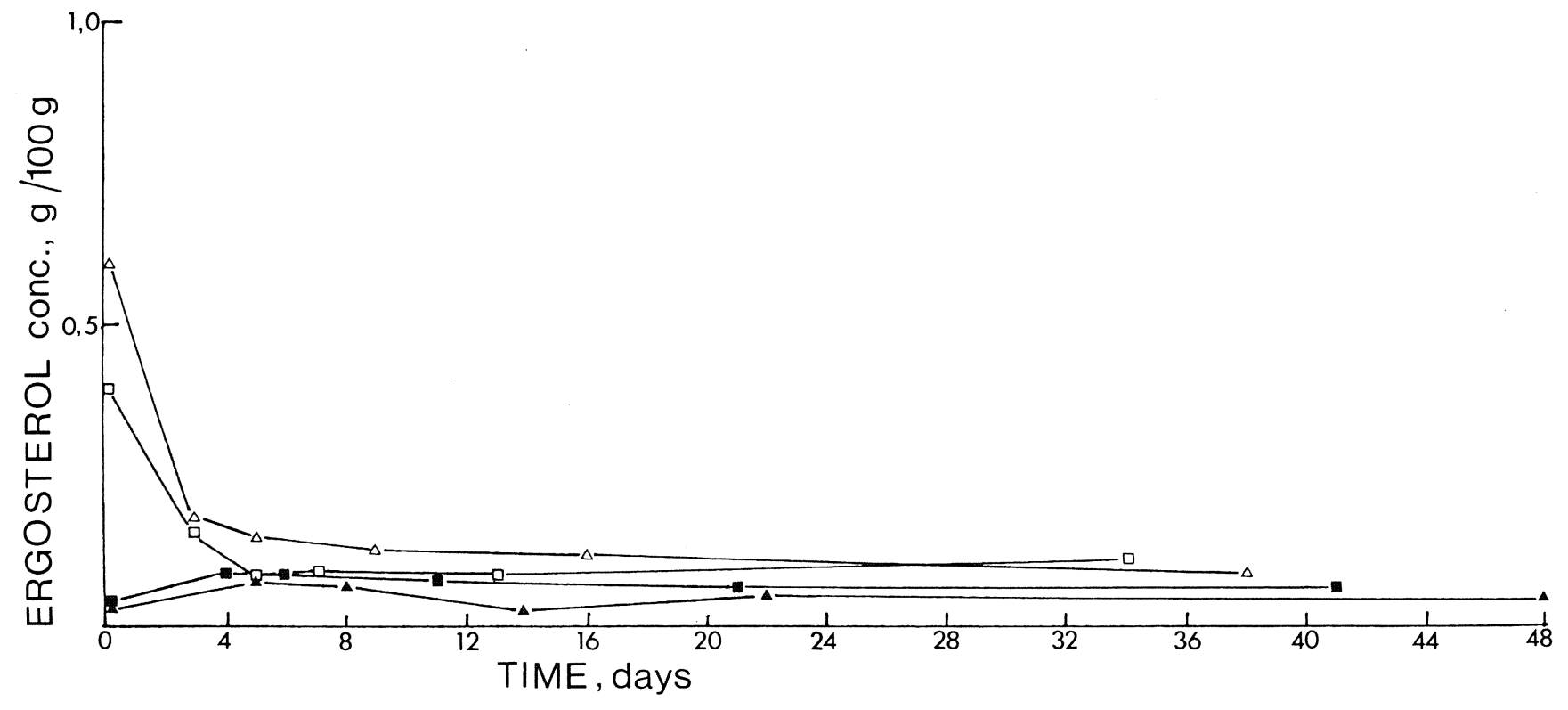

Fig. 13

Ergosterol concentration (dry mass basis) of aerated and unaerated pure cultures of two wine yeast strains of sterile filtered Chenin blanc must.

$\square$ WE 14 aerated; $\triangle$ WE 432 aerated;

TABLE 2

Comparison of aerated and unaerated cultures in respect of inocula, days fermented and final ergosterol concentrations.

\begin{tabular}{|c|c|c|c|c|}
\hline \multirow{2}{*}{ Strain } & \multirow[b]{2}{*}{$\begin{array}{l}\text { Inoculum } \\
\left(x 10^{6}\right. \\
\text { cells/m } /)\end{array}$} & \multirow[b]{2}{*}{$\begin{array}{l}\text { Days } \\
\text { fermented }\end{array}$} & \multicolumn{2}{|c|}{ Ergosterol } \\
\hline & & & $\begin{array}{l}\mathrm{g} / 100 \mathrm{~g} \\
\text { yeast }\end{array}$ & $\begin{array}{l}\mathrm{mg} / 50 \mathrm{~m} \ell \\
\text { medium }\end{array}$ \\
\hline \multicolumn{5}{|c|}{ Chenin blanc } \\
\hline $\begin{array}{l}\text { WE } 14 \text { U } \\
\text { WE } 14 \text { A }\end{array}$ & 1,025 & $\begin{array}{l}41 \\
34\end{array}$ & 0,04 & ,082 \\
\hline WE $432 \mathrm{U}$ & $\begin{array}{c}20,00 \\
0,635\end{array}$ & $\begin{array}{l}34 \\
48\end{array}$ & 0,02 & 045 \\
\hline WE $432 \mathrm{~A}$ & 8,935 & 38 & 0.59 & 133 \\
\hline $\begin{array}{l}\text { Colombar } \\
\text { WE 14 U }\end{array}$ & & & & \\
\hline $\begin{array}{l}\text { WE } 14 \mathrm{U} \\
\text { WE } 14 \mathrm{~A}\end{array}$ & 1,245 & $\begin{array}{l}46 \\
30\end{array}$ & $\begin{array}{l}0,02 \\
026\end{array}$ & , 086 \\
\hline WE $432 \mathrm{U}$ & 0,505 & 46 & 0,02 &, 054 \\
\hline WE $432 \mathrm{~A}$ & 8,025 & 38 & 0,63 & 144 \\
\hline
\end{tabular}

${ }^{\mathrm{a}} \mathrm{U}=$ unaerated, $\mathrm{A}=$ aerated

\section{CONCLUSIONS}

In the fermentation of grape must ergosterol plays an important part in the yeast cell, since the more rapid fermentation in either unfiltered or filtered must was accompanied by a relatively high ergosterol content. Similar observations have been reported by Larue, Lafon-Lafourcade \& Ribéreau-Gayon (1979) who found, in addition, that sterols and other so-called "survivial factors" permit the yeast to complete fermentation in the presence of higher sugar levels in the must.

The yeast strain producing most ergosterol in its cells does not necessarily produce the highest quantity of dry mass (for example strain WE 392 in the first experiment with clear settled juice). Thus ergosterol is probably not directly responsible for the formation of new cells, but may only be concerned with the physiological state of the cell, permitting it to maintain a higher level of activity and enabling it to complete fermentation more rapidly.
WE 14 unaerated;

$\triangle$ WE 432 unaerated

Aeration of a yeast culture greatly enhances ergosterol production. This treatment does not exert its effect only while being applied, but probably permits the yeast to maintain a more active metabolism leading to more rapid fermentation. During fermentation aerated cultures maintain a higher ergosterol concentration per dry mass, and their total ergosterol concentration per volume is also much higher. According to Jakobson \& Thorne (1980) yeasts growing in the presence of dissolved oxygen (aerobiosis) synthesize more sterols and unsaturated fatty acids than the minimum concentration necessary for growth, so that they do not have any demand for oxygen when placed in a new medium where conditions soon change to anaerobiosis. A further advantage of aeration is that aerated cultures have higher live cell counts. Its inoculation into another must therefore causes an earlier onset of fermentation than would be the case with an unaerated culture.

Strain WE 432 obviously has a disadvantage as regards the formation of new cells. Although efforts were made to obtain similar inoculation concentrations, strain WE 432 produced approximately three times less cells with aeration than did strain WE 14. Strain WE 432 was nevertheless a better ergosterol producer and contained a higher ergosterol concentration $(0,6 \mathrm{~g} / 100$ g) than the aerated strain WE $14(0,4 \mathrm{~g} / 100 \mathrm{~g})$ at the end of the aeration period. This result also proves that ergosterol is not directly connected with the formation of new cells.

Further studies are at present being undertaken to determine whether the general tendency of higher ergosterol concentration and faster fermentation rate applies to other wine yeast strains as well. The effect of different periods of aeration of pure cultures and its influence on wine quality are also investigated. 


\section{LITERATURE CITED}

ARIES, V., \& KIRSOP, B. H., 1978. Sterol biosynthesis by strains of Saccharomyces cerevisiae in the presence and absense of dissolved oxygen. J. Inst. Brew. 84, 188-122.

BERNDT, J., BOLL, M., LOWEL, M., \& GAUMERT, R., 1973. Regulation of sterol biosynthesis in yeast: induction of 3-hydroxy-3-methylglutaryl-coA reductase by glucose. Biochem. Biophys. Res. Commun. 51, 843-848.

BOLL, M., LÖWEL, M., STILL J., \& BERNDT, J., 1975. Sterol biosynthesis in yeast. Eur. J. Biochem. 54, 435-444.

BREIVIK, O. N., \& OWADES, J. L., 1957. Spectrophotometric semimicrodetermination of ergosterol in yeast. Agricultural and Food Chemistry 5, 360-363.

DAVID, M. H., \& KIRSOP, B. H., 1973. Yeast growth in relation to the dissolved oxygen and sterol content of wort. J. Inst. Brew. 79, 20-25.

DULANEY, E. L., STAPLEY, E. O., \& SIMPF, K., 1954. Studies on ergosterol production by yeasts. Appl. Microbiol. 2, 371-379.

HARDING, S. A., \& KIRSOP, B. H., 1979. Relative significance of oxygen and other nutrients as fermentation regulators in Saccharomyces cerevisiae. J. Inst. Brew. 85, 171-174.

JAKOBSEN, M., \& THORNE, R. S. W., 1980. Oxygen requirements of brewing strains of Saccharomyces uvarum (carlsbergensis) - bottom fermentation yeast. J. Inst. Brew. 86, 284-287.

KIRSOP, B. H., 1974. Oxygen in brewery fermentation. $J$. Inst. Brew. 80, 252-259.

KLEIN, H. P., 1955. Synthesis of lipids in resting cells of Saccharomyces cerevisiae. J. Bacteriol. 69, 620-627.

LAFON, S., 1978. Les stériodes "facteurs de survie" des levures au cours de la vinification. Ann. Technol. Agric. 27(1), 215-217.

LARUE, F., LAFON-LAFOURCADE, S., \& RIBÉREAU-GAYON, P., 1979. Les différents rôles fonctionnels des stéroïdes sur les levures dans le moût de raisin en fermentation: notion de facteur de survie. Ann. Microbiol. (Inst. Pasteur) 130A, 231-243.

MAS, J., \& PINA, E., 1980. Disappearance of nystatin resistance in Candida mediated by ergosterol. J. Gen. Microb. 117, 249-252.

PARKS, L. W., \& STARR, P. R., 1963. A relationship between ergosterol and respiratory competency in yeast. $J$. Cell. Comp. Physiol. 61, 61-65.

PROUDLOCK, J. W., HASLAM, J. M., \& LINNANE, A. W., 1969. Specific effect of unsaturated fatty acid depletion on mitochondrial oxidative phosphorylation in Saccharomyces cerevisiae. Biochem. Biophys. Res. Commun. 37, 847-852.

RATTRAY, J. B. M., SCHIBECI, A., \& KIDBY, D. K. 1975. Lipids of yeasts. Bacteriol. Rev. 39, 197-231. 